\title{
Recurrent Selection with Sub-Lethal Doses of Mesotrione Reduces Sensitivity in Amaranthus palmeri
}

\author{
Jason K. Norsworthy ${ }^{1, *}$, Vijay K. Varanasi ${ }^{1}$, Muthukumar Bagavathiannan ${ }^{2} \mathbb{D}$ and Chad Brabham ${ }^{1}$ \\ 1 Department of Crop, Soil, and Environmental Sciences, University of Arkansas, Fayetteville, AR 72701, USA; \\ vijaya.varanasi@gmail.com (V.K.V.); chad.brabham@fmc.com (C.B.) \\ 2 Department of Soil and Crop Sciences, Texas A \& M University, College Station, TX 77843, USA; \\ muthu@tamu.edu \\ * Correspondence: jnorswor@uark.edu; Tel.: +1-479-313-1265
}

Citation: Norsworthy, J.K.; Varanasi, V.K.; Bagavathiannan, M.; Brabham,

C. Recurrent Selection with

Sub-Lethal Doses of Mesotrione Reduces Sensitivity in Amaranthus palmeri. Plants 2021, 10, 1293. https://doi.org/10.3390/ plants10071293

Academic Editor: Baruch Rubin

Received: 20 May 2021

Accepted: 5 June 2021

Published: 25 June 2021

Publisher's Note: MDPI stays neutral with regard to jurisdictional claims in published maps and institutional affiliations.

Copyright: (C) 2021 by the authors. Licensee MDPI, Basel, Switzerland. This article is an open access article distributed under the terms and conditions of the Creative Commons Attribution (CC BY) license (https:// creativecommons.org/licenses/by/ $4.0 /)$.
Abstract: Amaranthus palmeri, ranked as the most prolific and troublesome weed in North America, has evolved resistance to several herbicide sites of action. Repeated use of any one herbicide, especially at lower than recommended doses, can lead to evolution of weed resistance, and, therefore, a better understanding of the process of resistance evolution is essential for the management of $A$. palmeri and other difficult-to-control weed species. Amaranthus palmeri rapidly developed resistance to 4-hydroxyphenylpyruvate dioxygenase (HPPD) inhibitors such as mesotrione. The objective of this study was to test the potential for low-dose applications of mesotrione to select for reduced susceptibility over multiple generations in an A. palmeri population collected from an agricultural field in 2001. $\mathrm{F}_{0}$ plants from the population were initially treated with sub-lethal mesotrione rates and evaluated for survival three weeks after treatment. All $\mathrm{F}_{0}$ plants were controlled at the $1 \times$ rate $\left(\mathrm{x}=105 \mathrm{~g}_{\text {ai ha }}{ }^{-1}\right)$. However, $2.5 \%$ of the $\mathrm{F}_{0}$ plants survived the $0.5 \times$ treatment. The recurrent selection process using plants surviving various mesotrione rates was continued until the $\mathrm{F}_{4}$ generation was reached. Based on the $\mathrm{GR}_{50}$ values, the sensitivity index was determined to be 1.7 for the $\mathrm{F}_{4}$ generation. Compared to $\mathrm{F}_{0}$, HPPD gene expression level in the $\mathrm{F}_{3}$ population increased. Results indicate that after several rounds of recurrent selection, the successive generations of $A$. palmeri became less responsive to mesotrione, which may explain the reduced sensitivity of this weed to HPPD-inhibiting herbicides. The results have significance in light of the recently released soybean and soon to be released cotton varieties with resistance to HPPD inhibitors.

Keywords: recurrent selection; weed resistance; non-target-site resistance; sub-lethal herbicide application; HPPD inhibitors; gene expression

\section{Introduction}

Amaranthus palmeriS. Watson (Palmer amaranth) is a problematic weed in North America, especially in mid-southern United States, due to its rapid growth rate, high fecundity, and a strong tendency to evolve resistance to several herbicide sites of action (SOA) [1-3]. Amaranthus palmeri has extensive genetic diversity being a dioecious and obligate outcrosser, which favors widespread herbicide resistance evolution in this species [4].

One of the herbicide classes to which $A$. palmeri rapidly evolved resistance was the 4-hydroxyphenylpyruvate dioxygenase (HPPD) inhibitors, commonly known as bleachers. Two of the first HPPD-inhibiting herbicides registered in the USA were isoxaflutole and mesotrione in 1998 and 2001, respectively. Resistance to HPPD inhibitors was first reported in Amaranthus tuberculatus (Moq.) Sauer (waterhemp) in 2009, and then in Palmer amaranth in 2012 [5,6]. Herbicides that inhibit HPPD are extensively applied preemergence and postemergence, mainly in maize and grain sorghum, to control a broad range of weed species, including A. palmeri. The HPPD-inhibiting herbicides have proven effective for controlling several glyphosate-, acetolactate synthase (ALS)-, and photosystem (PS) IIinhibitor-resistant weed biotypes $[7,8]$. However, due to the increasing incidents of HPPD- 
inhibitor resistance, a better understanding of weed resistance evolution to this chemistry is essential for sustaining its utility. This is especially important considering the recent commercialization of soybean with resistance to HPPD-inhibiting herbicides (LL ${ }^{\circledR}$ GT27 ${ }^{\mathrm{TM}}$ ) as well as the upcoming launch of cotton resistant to HPPD inhibitors (known as HPPDi cotton) $[9,10]$.

4-Hydroxyphenylpyruvate dioxygenase catalyzes the oxidative decarboxylation of 4-hydroxyphenylpyruvate (4-HPP) to form homogentisate (HGA) in the tocopherol biosynthetic pathway. Mesotrione (2-[4-(methylsulfonyl)-2-nitrobenzoyl]-1,3-cyclohexanedione) inhibits the HPPD enzyme, preventing the conversion of tyrosine to plastoquinone (PQ) and $\alpha$-tocopherol [11]. Plastoquinone is an essential component of carotenoid biosynthesis and the limited or no availability of PQ affects the downstream synthesis of carotenoids, which are essential for two critical roles during photosynthesis: light harvesting and protection against photooxidative damage [12,13]. Mesotrione treatment in sensitive species leads to reduced pigment biosynthesis and impaired chloroplast development.

Recommended or allowed use rates for herbicides are provided on the product labels to ensure they are consistently effective over broad environmental settings [14]. However, under certain conditions, reduced herbicide rates have been known to achieve comparable weed control levels in some cropping systems. From an economic standpoint, this creates a motive for growers with large acreages in developed countries to lower their herbicidal rates for attaining acceptable weed control levels [15]. However, in reality, weed populations are known to display high levels of genetic diversity and phenotypic plasticity, capable of tolerating low herbicide rates and control measures.

There are two major herbicide resistance mechanisms commonly reported in weeds, target- and non-target-site based. In general, spraying herbicides at higher rates favors the development of target-site, whereas lower than recommended rates favor non-target-site metabolic or creeping resistance [16,17]. Resistance to HPPD inhibitors in A. palmeri and A. tuberculatus was mainly found to be metabolic in nature [18,19].

Herbicides at sub-lethal rates can rapidly lead to non-target-site resistance in crosspollinated species $[15,20]$. Use of sub-lethal herbicide rates is known to result in selection and accumulation of non-target-site resistance mechanisms in subsequent generations [20]. Sub-lethal rates accumulate minor resistance conferring alleles (i.e., polygenic resistance), leading to the evolution of resistant phenotypes over several generations [21]. An increase in cases of non-target-site resistance in outcrossing species due to reduced herbicide usage has been documented in recent years $[15,20,22,23]$. Previously, low-dose recurrent selection leading to herbicide resistance has been reported for glyphosate and dicamba in A. palmeri, acetyl CoA carboxylase inhibitors in Lolium rigidum Gaudin (rigid ryegrass), and 2,4-D in Raphanus raphanistrum L. (wild radish) [15,20,24-26]. However, the consequences of lowdose selection for HPPD inhibitors in weed species, especially in A. palmeri, are not known. It has been suggested that the tolerance of $A$. palmeri to herbicides may be progressively increasing with each generation when applied at less than recommended rates [24].

Herbicide resistance resulting from a low-dose recurrent selection process is polygenic and metabolic in nature $[20,21]$. Previous studies with diclofop-methyl in rigid ryegrass have indicated rapid herbicide metabolism in low-dose selected populations (R1, R2) when compared to unselected populations $(\mathrm{S} 1, \mathrm{~S} 2)$ [27]. More recently, several studies have also associated increased target-site gene expression with the rapid detoxification process. One such study confirmed increased mesotrione metabolism and HPPD transcript levels in A. palmeri under high temperature conditions [28]. Increased HPPD gene expression (4- to 12-fold) and rapid mesotrione metabolism in resistant $A$. palmeri populations from Kansas and Nebraska have been reported [19]. However, to date, no one has studied the target-site gene expression in successive generations of low-dose recurrent selection in weed species. Does gene expression correlate with reduced herbicide sensitivity in successive generations?

The objectives of this study were to determine (1) the potential for sub-lethal doses of mesotrione to select for reduced susceptibility over multiple generations in an A. palmeri 
population collected in 2001, and (2) characterize the target-site HPPD gene expression in successive recurrent selections.

\section{Results}

\subsection{Low-Dose Mesotrione Selection}

Recurrent selection for two generations $\left(\mathrm{F}_{2}\right)$ resulted in an increase in the number of individuals surviving $1.0(56 \%)$ and $1.5 \times(37 \%)$ rates (Table 1$)$. Even at $\mathrm{F}_{3}$, there were a significant number of survivors ( 31 and $10 \%$ ) at 1.5 and $2.0 \times$ rates. These results indicate that after repeated recurrent selections, $\mathrm{F}_{2}{ }^{\prime} \mathrm{s}$ and $\mathrm{F}_{3}{ }^{\prime} \mathrm{s}$ became less susceptible to mesotrione compared to the initial $F_{0}$ generation. Dose-response curves and the corresponding $\mathrm{GR}_{50}$ values revealed reduced sensitivity to mesotrione for $F_{4}$ when compared to $F_{0}\left(F_{4} / F_{0}=1.7\right)$ (Table 2, Figures 1 and 2).

Table 1. A 2001 A. palmeri population $\left(\mathrm{F}_{0}\right)$ used for generating $\mathrm{F}_{1}, \mathrm{~F}_{2}, \mathrm{~F}_{3}$, and $\mathrm{F}_{4}$ lines. The table shows the mesotrione rates and the number of seedlings used in successive generations of the recurrent selection process. The survivors from each generation were allowed to cross and produce next generation seed. Dead/alive counts were recorded 3 weeks after treatment.

\begin{tabular}{cccc}
\hline & $\begin{array}{c}\text { Mesotrione Dose } \mathbf{( x )} \\
(\mathbf{1} \times \mathbf{1 0 5} \mathbf{g} \text { ai ha } \mathbf{~} \mathbf{1})\end{array}$ & $\begin{array}{c}\text { \# of Seedlings } \\
\text { Treated }\end{array}$ & Survivors (\%) \\
\cline { 2 - 4 } & 0.5 & 200 & 2.5 \\
\hline \multirow{2}{*}{$\mathrm{F}_{0}$} & 1.0 & 200 & 0 \\
\hline \multirow{2}{*}{$\mathrm{F}_{1}$} & 0.75 & 275 & 2.5 \\
\hline \multirow{2}{*}{$\mathrm{F}_{2}$} & 2.0 & 275 & 1.4 \\
\hline \multirow{2}{*}{$\mathrm{F}_{3}$} & 1.0 & 250 & 56 \\
\hline & 1.5 & 200 & 37 \\
\hline
\end{tabular}

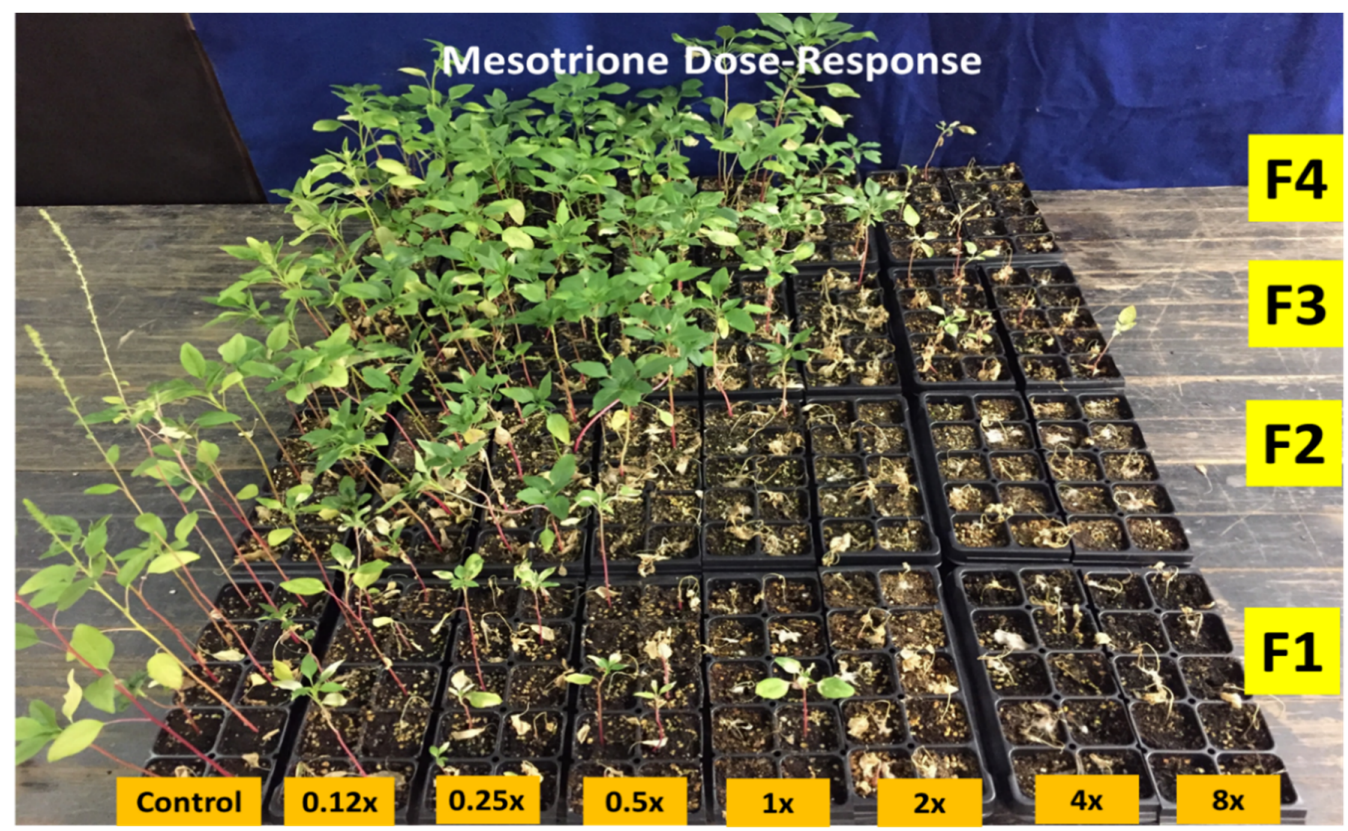

Figure 1. Generations of A. palmeri $\left(\mathrm{F}_{1}, \mathrm{~F}_{2}, \mathrm{~F}_{3}\right.$, and $\left.\mathrm{F}_{4}\right)$ treated with different mesotrione rates $\left(\mathrm{x}=105 \mathrm{~g}_{\mathrm{gi} \mathrm{ha}}{ }^{-1}\right)$. Picture taken 3 weeks after treatment. 
Table 2. The effective mesotrione doses $\left(\mathrm{g} \mathrm{ha}^{-1}\right)$ that caused $50 \%$ growth inhibition $\left(\mathrm{GR}_{50}\right)$ in different generations of $A$. palmeri collected from an agricultural field.

\begin{tabular}{ccc}
\hline Generation & $\mathbf{G R}_{\mathbf{5 0}}{ }^{\mathbf{a}}$ & Sensitivity Index $^{\mathbf{b}}$ \\
\hline $\mathrm{F}_{0}$ & $23.57(2.00)$ & - \\
\hline $\mathrm{F}_{2}$ & $39.96(3.33)$ & $1.5\left(\mathrm{~F}_{2} / \mathrm{F}_{0}\right)$ \\
\hline $\mathrm{F}_{3}$ & $39.60(3.33)$ & $1.5\left(\mathrm{~F}_{3} / \mathrm{F}_{0}\right)$ \\
\hline $\mathrm{F}_{4}$ & $41.22(5.07)$ & $1.7\left(\mathrm{~F}_{4} / \mathrm{F}_{0}\right)$ \\
\hline
\end{tabular}

a Numbers in parenthesis of $\mathrm{GR}_{50}$ values represent $\mathrm{SE} ;{ }^{\mathrm{b}}$ Sensitivity index for mesotrione calculated based on the $\mathrm{GR}_{50}$ values for each generation. $\mathrm{F}_{0}$ was used as the base population for the calculation.

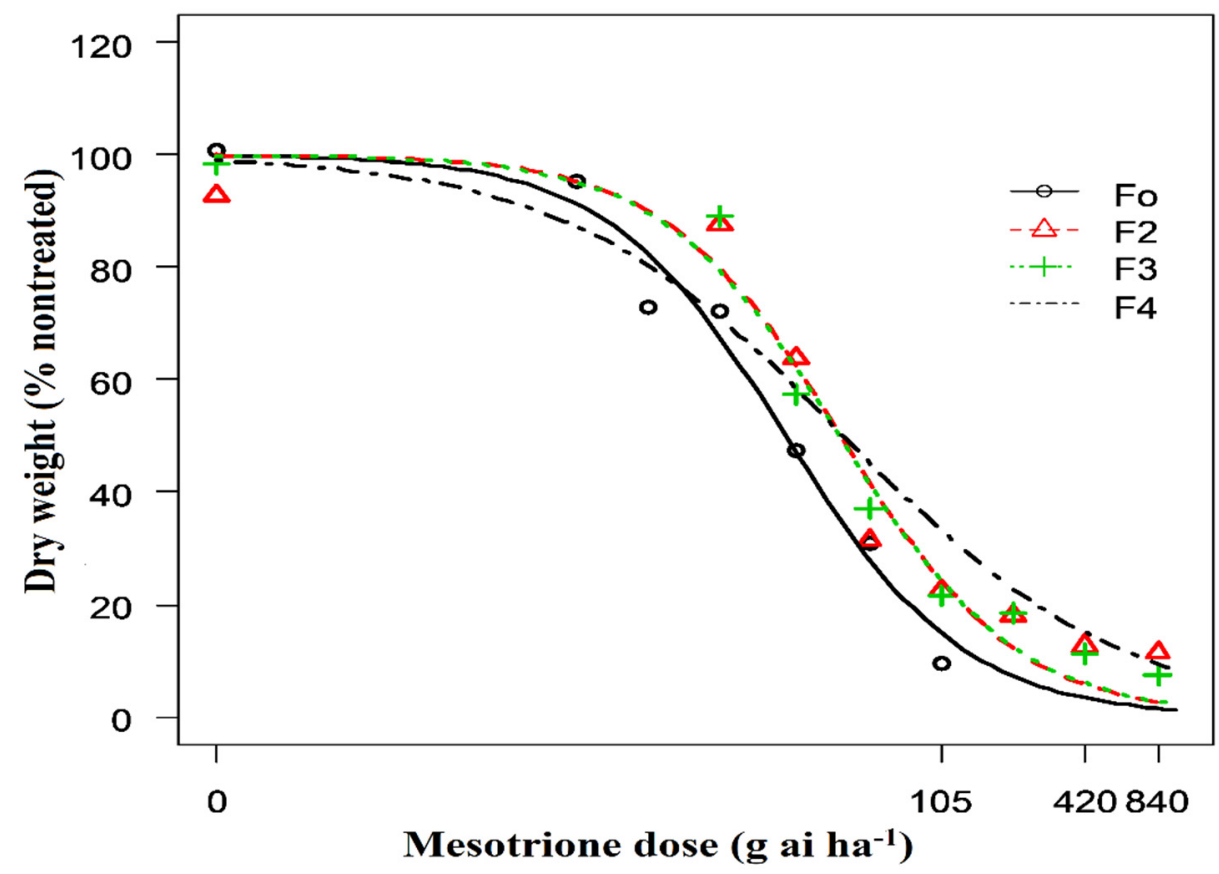

Figure 2. Dose-response curves for generations of A. palmeri $\left(\mathrm{F}_{0}-\mathrm{F}_{4}\right)$ selected following sub-lethal doses of mesotrione in the greenhouse.

\subsection{HPPD Gene Expression}

In this study, increased HPPD expression levels were observed in the $\mathrm{F}_{3}$ generation (Figure 3). HPPD expression remained low (near to $F_{0}$ levels) until the $F_{2}$, and a sudden spike was observed at the $F_{3}$ generation. The population had a 1.5-fold reduction in response to mesotrione at $\mathrm{F}_{3}$. 


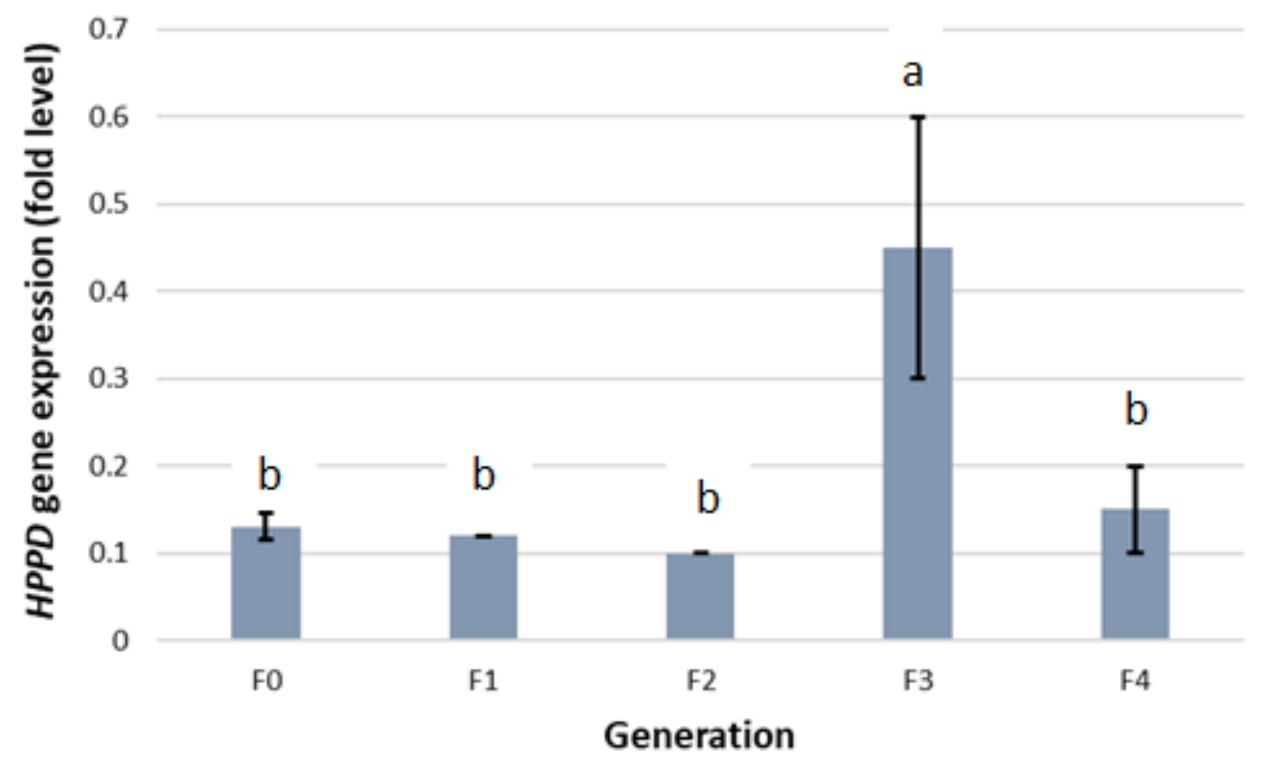

Figure 3. HPPD gene expression in A. palmeri generations $\left(\mathrm{F}_{0}, \mathrm{~F}_{1}, \mathrm{~F}_{2}, \mathrm{~F}_{3}, \mathrm{~F}_{4}\right)$. Gene expression was measured relative to the reference gene ( $\beta$-tubulin) and expressed in fold levels. Data represent means of biological replicates, and error bars represent SE. Different lowercase letters above bars represent statistical difference in treatments based on Tukeys HSD test.

\section{Discussion}

The recurrent selections conducted on the 2001 population resulted in a shift in reduced sensitivity to mesotrione (up to 1.7 -fold for the $\mathrm{F}_{4}$ generation). These data reveal that application of sub-lethal mesotrione rates over subsequent generations leads to reduced A. palmeri sensitivity to the herbicide, eventually leading to resistance based on the survival of offspring from selection to a labeled field rate of mesotrione. Factors such as biotype (biological) and herbicide dose (operational) are known to greatly impact the rate of resistance evolution [15].

Herbicide resistance due to sub-lethal selection occurs more rapidly in cross-pollinated than in self-pollinated species [21]. Amaranthus palmeri, being an obligate, cross-pollinated species due to dioecy, is more prone to herbicide resistance resulting from sub-lethal selection. The accumulation and increase in the frequency of genes having additive effects leads to a rise in reduced sensitivity to herbicides in cross-pollinated weed populations [15,29]. In general, the frequency of resistance alleles initially present in any population is a key driving force for evolution of herbicide resistance [30]. Sensitivity of the final selection revealed a $\mathrm{GR}_{50}$ of $41.22 \mathrm{~g}$ ai ha ${ }^{-1}$, which was significantly greater than the initial $\mathrm{GR}_{50}$ of $23.57 \mathrm{~g}$ ai ha $^{-1}$.

The reduced mesotrione susceptibility of $A$. palmeri observed in this study somewhat matches the reduced susceptibilities observed earlier for dicamba, 2,4-D, and glyphosate in this species following recurrent sub-lethal selection [24,26]. For Lolium rigidum, another outcrossing species, three cycles of low-dose selection resulted in a 56-fold increase in diclofop-methyl resistance [20], which may indicate that some major alleles were responsible for resistance. In the case of dicamba, three cycles of repeated selection were necessary to result in individuals capable of surviving the label rate $\left(560 \mathrm{~g}\right.$ ae ha $\left.{ }^{-1}\right)$ [26]. However, in our study, individuals surviving mesotrione at $105 \mathrm{~g}$ ai ha ${ }^{-1}$, the labeled rate, was reached in the second generation $\left(\mathrm{F}_{2}\right)$ (Table 1$)$. This shows that compared to other herbicide SOA, there is a more rapid evolution of sub-lethal dose-mediated mesotrione resistance in $A$. palmeri. The rapid selection for resistance to HPPD herbicides is not surprising considering the failure of a labeled rate of mesotrione $\left(105 \mathrm{~g}_{\mathrm{ai} \mathrm{ha}}{ }^{-1}\right)$ and tembotrione $\left(92 \mathrm{~g}\right.$ ai ha $\left.{ }^{-1}\right)$ to control A. palmeri accessions throughout Arkansas in recent screenings [31,32].

An increase in HPPD gene expression, a target-site based mechanism, leads to increased mesotrione resistance following low-dose selection. Nakka et al. [19] have previ- 
ously reported increased HPPD gene expression in mesotrione-resistant A. palmeri populations, while suggesting the role of cytochrome P450 monooxygenases (CYP450s) in the detoxification process. Cytochrome P450s have also been implicated in the non-targetsite-based resistance mechanism involving metabolism of mesotrione and other HPPD inhibitors in A. tuberculatus [18,33,34]. In addition to the target-site mechanism (HPPD overexpression) observed here, it is also likely that non-target-site (metabolic) resistance mechanisms may be contributing to the resistance in this population, which was not investigated in this study.

An increase in HPPD gene expression does not appear to be the likely cause of resistance in this A. palmeri population following recurrent selection. Findings from this research lead to the conclusion that it takes multiple cycles of low-dose recurrent selection for favorable alleles (most likely from the CYP450 family) to come together and have significant impact on mesotrione resistance, at least at the population size evaluated. Future efforts should evaluate expression of CYP450 genes and the effectiveness of the CYP450 inhibitor malathion in reversing resistance to HPPD-inhibiting herbicides. There should also be efforts to quantify mesotrione metabolism on recurrently selected populations to determine if the resistance level observed at $\mathrm{F}_{3}$ translates to rapid detoxification when compared to unselected populations $\left(\mathrm{F}_{0}\right)$. If overexpression of CYP450 genes is found and enhanced metabolism is documented, efforts should focus on identifying the specific genes responsible for this non-target-site resistance mechanism. It will be intriguing to see if this mesotrione-resistant population would also be cross-resistant to other herbicide chemistries. Additionally, data for mesotrione resistance in A. palmeri using this population could be useful for modeling the evolution of resistance to HPPD-inhibiting herbicides and developing management strategies that mitigate risk for polygenic resistance evolution.

Under greenhouse conditions, the use of sub-lethal mesotrione rates over several generations selected for resistance in this population was demonstrated. Recent screenings for sensitivity of A. palmeri accessions in Arkansas to mesotrione and tembotrione revealed that a highly variable response was present among sampled sites [31,32]. The evolution of mesotrione resistance under field conditions is possible if reduced herbicide rates are applied for economic reasons, weeds emerge as soil-applied activity of the herbicide partially dissipates, the herbicide is applied to larger weeds than recommended, or environmental conditions are such that they lead to reduced herbicide efficacy [35-37] because all these scenarios may allow for the selection and accumulation of minor effect resistance conferring alleles in the population. One strategy that continues to be recommended is to follow the label in all instances and diversify weed control tactics as much as possible [36]. Using diverse herbicides with residual activity for preemergence instead of relying solely on postemergence weed control integrated with non-chemical measures would also help with long-term resistance management.

\section{Materials and Methods}

\subsection{Parental Populations $\left(F_{0}\right)$}

Seeds of A. palmeri $\left(\mathrm{F}_{0}\right)$ were collected in Arkansas, United States, in 2001 from an agricultural field site. The field history of this site was unknown, but it is unlikely that these fields had ever been treated with mesotrione or another HPPD-inhibiting herbicide considering the lack of significant maize hectares in Arkansas prior to 2001 and the fact that HPPD herbicides were not widely used in Arkansas maize production prior to this time. When samples were collected, approximately 15-20 female plants were harvested per field, and seeds from these plants were combined into a composite sample, representing the population. Seeds were placed in dry storage at $4{ }^{\circ} \mathrm{C}$.

The susceptibility of the $\mathrm{F}_{0}$ population was confirmed in 2016 in a preliminary greenhouse study using mesotrione (Callisto ${ }^{\circledR}$, Syngenta Crop Protection, Greensboro, NC, USA) at $105 \mathrm{~g}$ ai ha ${ }^{-1}(1 \times$ rate). Greenhouse experiments, including selection, dose-response, and gene expression, were conducted during 2017 and 2018 at the Altheimer Laboratory, University of Arkansas, Fayetteville. The seed obtained from each selection cycle was 
planted in plastic trays $(25 \mathrm{~cm} \times 55 \mathrm{~cm})$, and after germination, seedlings at the 2-leaf stage were transplanted into 50-cell plastic trays (tray size: $25 \mathrm{~cm} \times 55 \mathrm{~cm}$ ) filled with potting mix (Sunshine premix No. $1{ }^{\circledR}$; Sun Gro Horticulture, Bellevue, WA, USA). A 16 h photoperiod using high-pressure sodium lamps $\left(400 \mu \mathrm{mol} \mathrm{m}^{-2} \mathrm{~s}^{-1}\right), 35 / 25^{\circ} \mathrm{C}$ day/night temperature regime, and a daily watering schedule was maintained throughout the greenhouse study.

\subsection{Generation of $F_{1}-F_{4}$}

All selections took place by treating 4- to 6-leaf $A$. palmeri plants grown in a greenhouse. Two rates of mesotrione were chosen for each selection, with the goal of achieving approximately $90-95 \%$ mortality across the rates. The $\mathrm{F}_{0}$ plants were treated with mesotrione at 0.5 and $1 \times$ rates (Table 1 ). $\mathrm{F}_{0}$ survivors from the $0.5 \times$ rate were allowed to grow in isolation in the greenhouse and cross-pollinate to produce $\mathrm{F}_{1}$ seed. In the next selection cycle, $\mathrm{F}_{1}$ plants were treated with 0.75 and $2 \times$ doses of mesotrione, and survivors from both doses were allowed to produce $F_{2}$ seed in isolation (Table 1). The $F_{2}$ seed from the 0.75 and $2 \times$ doses were combined and used for further selection cycles with increasing mesotrione rates until $\mathrm{F}_{3}$ and $\mathrm{F}_{4}$ seeds were generated (Table 1). Each selection cycle in the greenhouse was completed in a five- to six-month period: January-May $2017\left(\mathrm{~F}_{1}\right)$, June-November $2017\left(\mathrm{~F}_{2}\right)$, December 2017-April $2018\left(\mathrm{~F}_{3}\right)$, and May-October $2018\left(\mathrm{~F}_{4}\right)$.

\subsection{Dose-Response Experiments}

Dose-response assays were run on the selections in the greenhouse to determine the level of mesotrione resistance in each cycle (as discussed above). The experiment was a randomized complete block design with 3 replications (10 plants replication $\left.{ }^{-1}\right)$ and was conducted in two runs. Seed obtained from $\mathrm{F}_{0}, \mathrm{~F}_{2}\left(0.75 \times\right.$ selection), $\mathrm{F}_{3}(1 \times)$, and $\mathrm{F}_{4}(1.5 \times)$ was used in the dose-response assays. Adequate $\mathrm{F}_{1}$ seed was not available and therefore was not included in the dose-response experiment.

Amaranthus palmeri seedlings at 4- to 6-leaf growth stage were treated with increasing rates of mesotrione. The following mesotrione rates were used for the $\mathrm{F}_{0}$ generation: 0 , $0.03,0.06,0.12,0.25,0.5$, and $1.0 \times$. The rates were chosen based on the initial sensitivity of the $\mathrm{F}_{0}$ population. For $\mathrm{F}_{2}$ through $\mathrm{F}_{4}$ generations, mesotrione rates utilized for the dose-response study were: $0,0.12,0.25,0.5,1.0,2.0,4.0$, and $8.0 \times$. Crop oil concentrate (Superb $^{\circledR}$ HC, Winfield Solutions, St. Paul, MN, USA) at $1 \% v / v$ was included as an adjuvant in all treatments as recommended by the product label [29]. A research track sprayer equipped with two 800067 flat-fan spray nozzles (TeeJet spray nozzles; Spraying Systems Co., Wheaton, IL, USA) calibrated to deliver $187 \mathrm{~L} \mathrm{ha}^{-1}$ of herbicide solution at $269 \mathrm{kPa}$, moving at a speed of $1.6 \mathrm{~km} \mathrm{~h}^{-1}$, was used for applying treatments to plants. Percent survival (based on regrowth) and aboveground dry biomass data were collected $3 \mathrm{wk}$ after treatment (WAT). Aboveground fresh biomass from the plants was harvested in paper bags, oven-dried at $65^{\circ} \mathrm{C}$ for $3 \mathrm{~d}$, and then expressed as a percentage of the nontreated for dose-response curves.

\subsection{Data Analysis}

In this study, there was no significant treatment by run interaction $(p>0.05)$. Therefore, dose-response data were pooled between the two experimental runs for analysis. The dose-response analysis was conducted on the aboveground dry biomass data using the drc package in R 3.1.2 [38]. A four-parameter log-logistic model [39] was used to define the relationship between herbicide rates used and the corresponding dry biomass:

$$
Y=C+\frac{D-C}{1+\exp \left\{b[\log (x)]-\log \left(G R_{50}\right)\right\}}
$$

where $Y$ is the response (aboveground dry biomass) expressed as a percent nontreated, $C$ and $D$ are the lower and upper asymptotes of $Y, b$ is the slope of the curve around the $\mathrm{GR}_{50}$ (herbicide dose required for $50 \%$ reduction in biomass), and $x$ is the herbicide dose. 
Resistance or sensitivity index (resistance/susceptibility (R/S)) for each generation was calculated based on the respective $\mathrm{GR}_{50}$, using $\mathrm{F}_{0}$ as the base population (Table 2).

\subsection{RNA Extraction, cDNA Synthesis, and Quantitative PCR}

The developing, non-fully expanded youngest leaf was harvested $3 \mathrm{~d}$ after treatment (DAT) (mesotrione at $1 \times$ ) in $1.5 \mathrm{~mL}$ microfuge tubes (Thermo Fisher Scientific, Waltham, MA, USA) and stored at $-80^{\circ} \mathrm{C}$ for RNA extraction. The frozen leaf tissue was homogenized in liquid nitrogen using a prechilled mortar and pestle. The powdered tissue was transferred to a prechilled $1.5 \mathrm{~mL}$ microcentrifuge tube, and total RNA was isolated using the recommended protocol of TRIzol ${ }^{\circledR}$ reagent (Thermo Fisher Scientific, Waltham, MA, USA). To remove contamination due to genomic DNA, ribonucleic acid was treated with DNase 1 enzyme (Thermo Fisher Scientific, Waltham, MA, USA). Total RNA was quantified using a spectrophotometer (NanoDrop 1000, Thermo Fisher Scientific, Waltham, MA, USA) and its integrity checked using agarose gel (1\%) electrophoresis. About $1 \mu \mathrm{g}$ of the total RNA was converted to complementary DNA (cDNA) using a RevertAid First Strand cDNA Synthesis Kit (Thermo Fisher Scientific, Waltham, MA, USA).

A SYBR Green quantitative PCR (qPCR) assay was performed to study the expression of the HPPD gene in successive generations $\left(\mathrm{F}_{0}\right.$ to $\left.\mathrm{F}_{3} / \mathrm{F}_{4}\right)$ of the two populations after mesotrione application. The qPCR reaction mix $(10 \mu \mathrm{L})$ contained $5 \mu \mathrm{L}$ of PowerUP SYBR Green mastermix (Applied Biosystems, Waltham, MA, USA), $1 \mu \mathrm{L}$ each of forward and reverse gene specific primers $(5 \mu \mathrm{M}), 1 \mu \mathrm{L}$ of nuclease-free water, and $2 \mu \mathrm{L}$ of the target cDNA. The forward and the reverse gene specific primers for amplifying the HPPD were $5^{\prime}$-TGAAACCCGAAAATCAACCCG- $3^{\prime}$ and $5^{\prime}$-TGTATCTGGAACCTGTTTACG- ${ }^{\prime}$. The primers were designed based on the $A$. tuberculatus sequence information available online (KY689232.1) [40]. $\beta$-tubulin was used as a reference gene for normalizing the HPPD gene expression [28]. The qPCR was run at $50{ }^{\circ} \mathrm{C}$ for $2 \mathrm{~min}, 95^{\circ} \mathrm{C}$ for $2 \mathrm{~min}$, and 40 cycles of $95^{\circ} \mathrm{C}$ for $30 \mathrm{~s}$, and $59^{\circ} \mathrm{C}$ for $1 \mathrm{~min}$, respectively. The qPCR protocol was followed by a melt curve profile to determine the specificity of the qPCR product. A $2^{\Delta \mathrm{Ct}}$ method was utilized to measure the relative HPPD: $\beta$-tubulin expression, where $\mathrm{Ct}$ is threshold cycle and $\triangle \mathrm{Ct}$ is $\mathrm{Ct}_{\text {Reference gene ( } \beta \text {-tubulin) }}-\mathrm{CT}_{\text {Target gene (PPX2) }}$. Standard errors were generated using three biological and three technical replicates. Change in levels of HPPD gene expression in $F_{1}, F_{2}, F_{3}$, and $F_{4}$ generations were compared to the base $F_{0}$ levels for analysis. Gene expression data were analyzed by ANOVA and Tukey's HSD test.

Author Contributions: Conceptualization, J.K.N. and M.B.; data collection, V.K.V. and C.B.; writingoriginal draft, V.K.V.; writing-review and editing, J.K.N. and M.B.; funding acquisition, J.K.N. and M.B. All authors have read and agreed to the published version of the manuscript.

Funding: Partial support provided by Syngenta Crop Protection and Bayer CropScience.

Institutional Review Board Statement: Not applicable.

Informed Consent Statement: Not applicable.

Data Availability Statement: Not applicable.

Conflicts of Interest: The authors declare no conflict of interest.

\section{References}

1. Van Wychen, L. A 2016 Survey of the Most Common and Troublesome Weeds in Broadleaf Crops, Fruits and Vegetables in the United States and Canada. 2016. Available online: http://wssa.net/wp-content/uploads/2016_Weed_Survey_Final.xlsx (accessed on 8 May 2021).

2. Korres, N.E.; Norsworthy, J.K. Palmer amaranth (Amaranthus palmeri) demographic and biological characteristics in wide-row soybean. Weed Sci. 2017, 65, 491-503. [CrossRef]

3. Heap, I. The International Survey of Herbicide Resistant Weeds. 2021. Available online: http://weedscience.com/Home.aspx (accessed on 8 May 2021).

4. Ward, S.M.; Webster, T.; Steckel, L.E. Palmer amaranth (Amaranthus palmeri): A review. Weed Technol. 2013, 27, 12-27. [CrossRef] 
5. Hausman, N.E.; Singh, S.; Tranel, P.J.; Riechers, D.E.; Kaundun, S.S.; Polge, N.D.; Thomas, D.A.; Hager, A.G. Resistance to HPPD-inhibiting herbicides in a population of waterhemp (Amaranthus tuberculatus) from Illinois, United States. Pest Manag. Sci. 2011, 67, 258-261. [CrossRef]

6. Thompson, C.R.; Peterson, D.E.; Lally, N.G. Characterization of HPPD-resistant Palmer amaranth. In Proceedings of the 52th Annual Conference of the Weed Science Society of America, Waikoloa, HI, USA, 6-9 February 2012.

7. Sutton, P.; Richards, C.; Buren, L.; Glasgow, L. Activity of mesotrione on resistant weeds in maize. Pest Manag. Sci. 2002, 58, 981-984. [CrossRef] [PubMed]

8. Starkey, C.E.; Norsworthy, J.K.; Schwartz, L.M. Use of HPPD-inhibiting herbicides for control of troublesome weeds in the Midsouthern United States. Adv. Crop Sci. Technol. 2015, 4. [CrossRef]

9. Gottula, J.; Chapman, K.; Gao, Y.; Gillikin, N.; Beale, J.; Dharmasri, C.; Privalle, L. Agronomic performance and crop composition of genetically engineered cotton tolerant to HPPD inhibiting herbicides. J. Cotton Sci. 2018, 22, 75-85.

10. Nandula, V.K. Herbicide Resistance Traits in Maize and Soybean: Current Status and Future Outlook. Plants 2019, 8, 337. [CrossRef]

11. Mitchell, G.; Bartlett, D.W.; Fraser, T.E.M.; Hawkes, T.R.; Holt, D.C.; Townson, J.K.; Wichert, R.A. Mesotrione: A new selective herbicide for use in maize. Pest Manag. Sci. 2001, 57, 120-128. [CrossRef]

12. Norris, S.R.; Barrette, T.R.; DellaPenna, D. Genetic dissection of carotenoid synthesis in Arabidopsis defines plastoquinone as an essential component of phytoene desaturation. Plant Cell 1995, 7, 2139-2149.

13. Ruiz-Sola, M.Á.; Rodríguez-Concepción, M. Carotenoid Biosynthesis in Arabidopsis: A Colorful Pathway. Arab. Book 2012, 10, e0158. [CrossRef]

14. Doyle, P.; Stypa, M. Reduced herbicide rates-A Canadian perspective. Weed Technol. 2004, 18, 1157-1165. [CrossRef]

15. Neve, P.; Powles, S. Recurrent selection with reduced herbicide rates results in the rapid evolution of herbicide resistance in Lolium rigidum. Theor. Appl. Genet. 2005, 110, 1154-1166. [CrossRef] [PubMed]

16. Gressel, J. Creeping resistances: The outcome of using marginally effective or reduced rates of herbicide. Brighton Crop Prot. Conf. Weeds 1995, 2, 587.

17. Gardner, S.N.; Gressel, J.; Mangel, M. A revolving dose strategy to delay the evolution of both quantitative vs major monogene resistances to pesticides and drugs. Int. J. Pest Manag. 1998, 44, 161-180. [CrossRef]

18. Ma, R.; Kaundun, S.S.; Tranel, P.J.; Riggins, C.W.; McGinness, D.L.; Hager, A.G.; Hawkes, T.; McIndoe, E.; Riechers, D.E. Distinct detoxification mechanisms confer resistance to mesotrione and atrazine in a population of waterhemp. Plant Physiol. 2013, 163, 368-377. [CrossRef]

19. Nakka, S.; Godar, A.S.; Wani, P.S.; Thompson, C.R.; Peterson, D.E.; Roelofs, J.; Jugulum, M. Physiological and molecular characterization of hydroxyphenylpyruvate dioxygenase (HPPD)-inhibitor resistance in Palmer amaranth (Amaranthus palmeri $\mathrm{S}$. Wats.). Front. Plant Sci. 2017, 8, 555. [CrossRef] [PubMed]

20. Neve, P.; Powles, S.B. High survival frequencies at low herbicide use rates in populations of Lolium rigidum result in rapid evolution of herbicide resistance. Heredity 2005, 95, 485-492. [CrossRef]

21. Busi, R.; Neve, P.; Powles, S.B. Evolved polygenic herbicide resistance in Lolium rigidum by low-dose herbicide selection within standing genetic variation. Evol. Appl. 2013, 6, 231-242. [CrossRef] [PubMed]

22. Busi, R.; Powles, S.B. Evolution of glyphosate resistance in a Lolium rigidum population by glyphosate selection at sub-lethal doses. Heredity 2009, 103, 318-325. [CrossRef] [PubMed]

23. Renton, M.; Diggle, A.; Manalil, S.; Powles, S. Does cutting herbicide rates threaten the sustainability of weed management in cropping systems? J. Theor. Biol. 2011, 283, 14-27. [CrossRef]

24. Norsworthy, J.K. Repeated sublethal rates of glyphosate lead to decreased sensitivity in Palmer amaranth. Crop Manag. 2012, 11, 1-6. [CrossRef]

25. Ashworth, M.B.; Walsh, M.J.; Flower, K.C.; Powles, S.B. Recurrent selection with reduced 2,4-D amine doses results in the rapid evolution of 2,4-D herbicide resistance in wild radish (Raphanus raphanistrum L.). Pest Manag. Sci. 2016, 72, 2091-2098. [CrossRef] [PubMed]

26. Tehranchian, P.; Norsworthy, J.K.; Powles, S.; Bararpour, M.T.; Bagavathiannan, M.V.; Barber, T.; Robert, C.S. Recurrent sublethal-dose selection for reduced susceptibility of Palmer amaranth (Amaranthus palmeri) to dicamba. Weed Sci. 2017, 65, 206-212. [CrossRef]

27. Yu, Q.; Han, H.P.; Cawthray, G.; Wang, S.F.; Powles, S.B. Enhanced rates of herbicide metabolism in low herbicide-dose selected resistant Lolium rigidum. Plant Cell Environ. 2013, 36, 818-827. [CrossRef] [PubMed]

28. Godar, A.S.; Varanasi, V.K.; Nakka, S.; Prasad, P.V.V.; Thompson, C.R.; Mithila, J. Physiological and molecular mechanisms of differential sensitivity of Palmer amaranth (Amaranthus palmeri) to mesotrione at varying growth temperatures. PLoS ONE 2015, 10, e0126731. [CrossRef] [PubMed]

29. Busi, R.; Girotto, M.; Powles, S.B. Response to low-dose herbicide selection in self-pollinated Avena fatua. Pest Manag. Sci. 2016, 72, 603-608. [CrossRef] [PubMed]

30. Jasieniuk, M.; Brûlé-Babel, A.L.; Morrison, I.N. The evolution and genetics of herbicide resistance in weeds. Weed Sci. 1996, 44, 176-193. [CrossRef]

31. González-Torralva, F.; Norsworthy, J.K.; Piveta, L.B.; Varanasi, V.K.; Barber, T.; Brabham, C. Susceptibility of Arkansas A. palmeri accessions to common herbicide sites of action. Weed Technol. 2021, in press. 
32. Singh, S.; Roma-Burgos, N.; Singh, V.; Alcober, E.A.L.; Salas-Perez, R.; Shivrain, V. Differential response of Arkansas Palmer amaranth (Amaranthus palmeri) to glyphosate and mesotrione. Weed Technol. 2018, 32, 579-585. [CrossRef]

33. Oliveira, M.C.; Gaines, T.A.; Dayan, F.E.; Patterson, E.; Jhala, A.J.; Knezevic, S.Z. Reversing resistance to tembotrione in an Amaranthus tuberculatus (var. rudis) population from Nebraska, USA with cytochrome P450 inhibitors. Pest Manag. Sci. 2018, 74, 2296-2305. [CrossRef]

34. Oliveira, M.C.; Gaines, T.A.; Jhala, A.J.; Knezevic, S.Z. Inheritance of mesotrione resistance in an Amaranthus tuberculatus (var. rudis) population from Nebraska, USA. Front. Plant Sci. 2018, 9, 60. [CrossRef]

35. Norsworthy, J.K.; Oliver, L.R.; Purcell, L.C. Diurnal leaf movement effects on spray interception and glyphosate efficacy. Weed Technol. 1999, 13, 466-470. [CrossRef]

36. Norsworthy, J.; Ward, S.M.; Shaw, D.R.; Llewellyn, R.S.; Nichols, R.L.; Webster, T.; Bradley, K.W.; Frisvold, G.; Powles, S.B.; Burgos, N.R.; et al. Reducing the risks of herbicide resistance: Best management practices and recommendations. Weed Sci. 2012, 60, 31-62. [CrossRef]

37. Koger, C.H.; Poston, D.H.; Reddy, K.N. Effect of glyphosate spray coverage on control of pitted morningglory (Ipomoea lacunosa). Weed Technol. 2004, 18, 124-130. [CrossRef]

38. R Core Team. R: A Language and Environment for Statistical Computing Computer Program, Version 3.6.1; R Foundation for Statistical Computing: Vienna, Austria, 2019. Available online: http:/ / www.r-project.org (accessed on 8 May 2021).

39. Seefeldt, S.S.; Jensen, J.E.; Fuerst, E.P. Log-logistic analysis of herbicide dose-response relationships. Weed Technol. 1995, 9, $218-227$. [CrossRef]

40. Owczarzy, R.; Tataurov, A.V.; Wu, Y.; Manthey, J.A.; McQuisten, K.A.; Almabrazi, H.G.; Pedersen, K.F.; Lin, Y.; Garretson, J.; McEntaggart, N.O.; et al. IDT SciTools: A suite for analysis and design of nucleic acid oligomers. Nucleic Acids Res. 2008, 36, W163-W169. [CrossRef] [PubMed] 